G. Wolfgang Heinze, Heinrich H. Kill

\title{
The Development of the German Railroad System
}

Chapter in book | Published version

This version is available at https://doi.org/10.14279/depositonce-7262

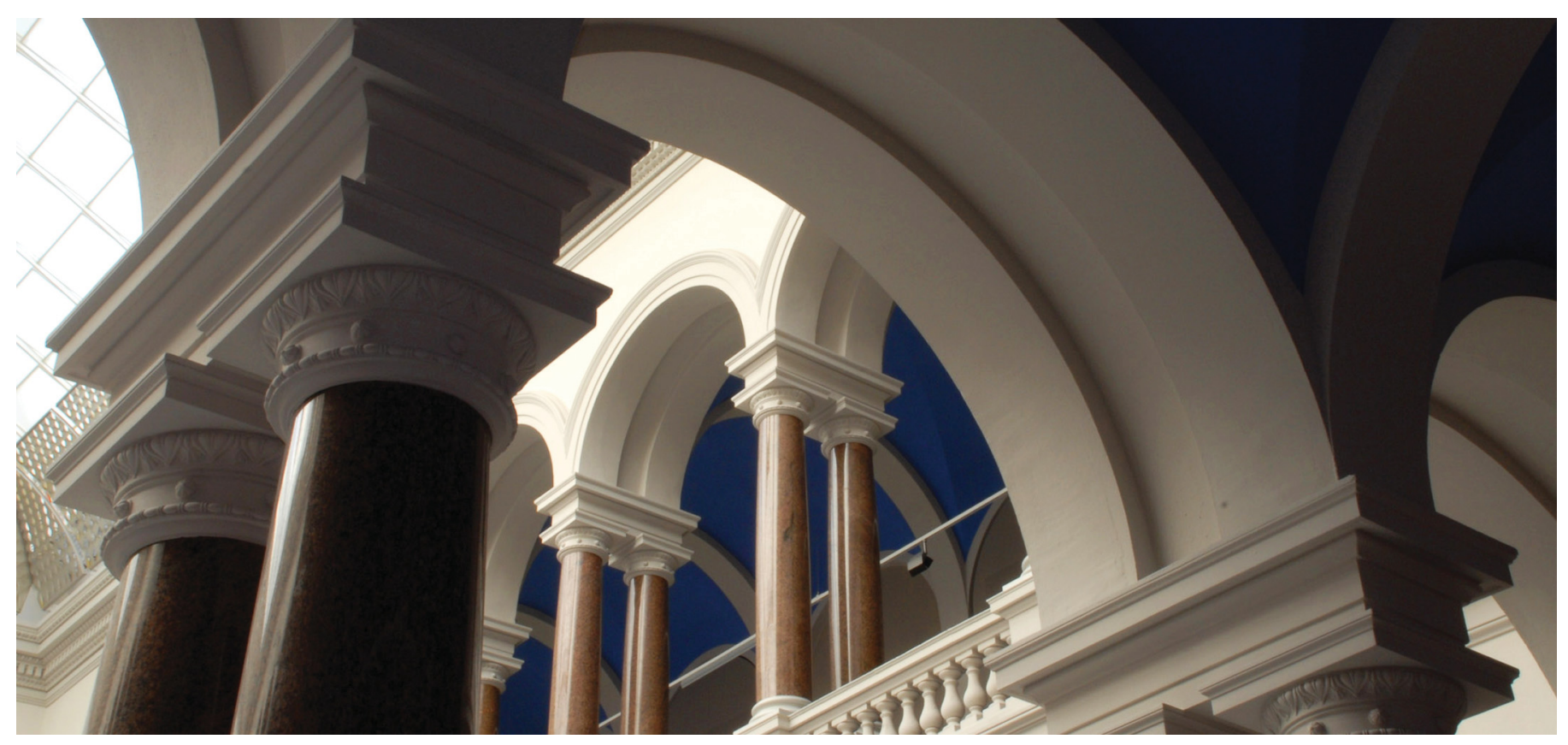

G. Wolfgang Heinze, Heinrich H. Kill (1988): The Development of the German Railroad System. In:

Mayntz, R.; Hughes, T. P. (Eds.): The Development of Large Technical Systems. (Schriften des Max-

Planck-Instituts für Gesellschaftsforschung Köln ; 2). Frankfurt am Main: Campus Verlag. pp. 105-134. 
CHAPTER 4

THE DEVELOPMENT OF THE GERMAN RAILROAD SYSTEM

G. Wolfgang Heinze and Heinrich $H$. Kill

\section{Patterns of growth: An overview}

Looking at the historical development of the German railroad network, one can identify four stages of development ${ }^{x}$. The primary stage (from about 1815 to 1840 ) involves the period when the original concept of building railways evolved and the first linkages of local importance were realized. During the following period (1841 to around 1875), connections between all the cities were built. During the third stage, which ended with the First World War, the existing lines were extended into rural areas and a feeder network was established. ${ }^{2}$ The final stage, which continues into the present, is characterized by the decline of the German railroad system. This stage began with a period where railroad construction stagnated during the 1920 s and led to the first closures of unproductive lines in the 1930s. Although this trend was arrested during the Second World War and its aftermath, these closures continued and were intensified during the last three decades. The connections remaining were adapted to advanced railway technology to meet present and future demands (Figure 1).

An analysis of other large technical systems indicates that this pattern of development is in no way unusual. A closer look at other transportation systems, as for example the development of inland water transport, inner city transit systems, or that of motorized road traffic similarly reveals four stages:

1. invention and isolated introduction (localized linkage),

2. demand-oriented construction (integration) - fulfilling only the needs of existing business centers, 
Figure 1: Stages of German Railway Development

\begin{tabular}{|c|c|c|}
\hline Petiod & General characteristics & German railways \\
\hline $\begin{array}{l}\text { Primary stage } \\
(1815-1841)\end{array}$ & $\begin{array}{l}\text { Invention and isolated } \\
\text { introduction } \\
\text { (isolated linkages) }\end{array}$ & $\begin{array}{l}\text { The original concept of building railways } \\
\text { evolves (abroad): mostly private companies } \\
\text { realize first linkages of local importance. }\end{array}$ \\
\hline $\begin{array}{l}\text { Secondary } \\
\text { stage } \\
(1842-1875)\end{array}$ & $\begin{array}{l}\text { Demand-oriented } \\
\text { construction (integra- } \\
\text { tion) }\end{array}$ & $\begin{array}{l}\text { Connections are built between all major } \\
\text { cities; governmental influence and even } \\
\text { management grow. }\end{array}$ \\
\hline $\begin{array}{l}\text { Tertiary } \\
\text { stage } \\
(1876-1913)\end{array}$ & $\begin{array}{l}\text { Demand and supply- } \\
\text { oriented extension } \\
\text { (intensification) }\end{array}$ & $\begin{array}{l}\text { The state-owned but independent } \\
\text { "Länderbahnen" in the German states } \\
\text { are developed. } \\
\text { Existing lines are extended into rural aras } \\
\text { and a feeder network is established. }\end{array}$ \\
\hline $\begin{array}{l}\text { Final stage } \\
(1920 \text { till } \\
\text { today) }\end{array}$ & $\begin{array}{l}\text { Maintenance oriented } \\
\text { "cut back" (selection) }\end{array}$ & $\begin{array}{l}\text { The Reichsbahn company is founded and } \\
\text { the German railioad system declines. Railway } \\
\text { construction stagnates in the } 20 \text { s: first closures } \\
\text { of unproductive lines follow in the } 30 \text { s. More } \\
\text { feeder lines are closed after wWII, the remai- } \\
\text { ning connections are adapted to advanced } \\
\text { railway technology. }\end{array}$ \\
\hline
\end{tabular}


3. supply-oriented extension (intensification) - supplying even the remote parts of the country motivated by the belief in equal access rights,

4. maintenance-oriented "cut back" (selection) - accepting efficiency as a basic principle and taking into account that different systems might complement each other. (In the case of road and freeway traffic the last stage has not yet been fully developed.)

One might therefore conclude that this is a general pattern in the development of successful technical systems serving a specific function. Whether system development will be successful is decided in the early stages of the process. The first decades of the German railroad system are also an excellent example of the decisive importance which the environment has for the system's chances of being successful. This paper will therefore concentrate on the first two stages of railway development we have identified in the beginning. We shall show in more detail that the development of the German railways was a sober economic affair of local interests. To overcome transportation bottlenecks, an existing technology was used in a new field and combined with another innovation of the era. The solution was found by engineers and travellers who were exposed to new ideas of solving problems tried by enterprises in England. The commitment of a few men led to independent innovative actions of a few communities. The overwhelming response of the social environment shows that the specific historical situation evoked transportation innovations and made the superior variant "railways" the superinnovation of bridging space. The polity only reacted to these events: Because it was a success, railway building became a favorite tool of governments.

The key elements of the German railroad era can be summed up in seven theses which will structure our argument.

1. Railways initially confronted rulers with a dilemma: On the one hand the railways were a very efficient or even necessary way to improve the economic situation and raise revenues, but on the other hand they increased the wealth and power of the bourgeoisie. Political response to the technical innovation was therefore ambivalent.

2. Time was ripe for a change because the old structures had reached their limits. In comparison to England, Germany was economically underdeveloped, though industrialization had already started. Population growth was high and labor migrated from the country into 
the towns. Politically Germany was a loose confederation of 33 independent states (Deutscher Bund), which induced a deep desire for unification. Power was divided: Kings and the aristocracy held political power, while the bourgeoisie had the economic power. This historical situation with its various strains affected railroad development deeply.

3. In the initial phase there was a market for the railway, but most of the actors did not know it. The railway came on the stage when the general demand for transport had already grown enormously, but for most people improvements of existing transport facilities (waterways, roads, vehicles and traffic organization) seemed to be more than sufficient to meet new demands.

4. There were few who understood the new technical system and its rules. Most actors were caught in a cage of traditional thinking.

5. The fact that railway technology was introduced by transfer from abroad shaped the emerging system.

6. The state strongly influenced railway building, though private enterprises constructed and owned most of them.

7. The success of this technological innovation was its mass effect: Rising utilization led to profits and cost reductions, which triggered a positive feedback making the railways the leading sector of German industrialization.

The railway was more than a new means of transportation with higher capacity. It opened new psychological, social, economic, political, and military dimensions, maybe comparable to the first flight across the Atlantic or the first landing on the moon. Until the advent of the railway, transportation was mostly dependent upon horses, the force of wind and the speed of running water. Travelling was a tough business, costly, slow and risky. Horses and carriages were something for the rich and powerful. In Germany the ordinary man went over long distances on foot. The railway changed all that. This new way of space-bridging and mobility led to a new perception of space, distances, speed and time. And this new means of transportation was not only something for big cities but could be used by everybody to go nearly everywhere and in all directions. The world shrank and the multistate system became an anachronism. At the same time, however, new kinds of accidents caused fear, and technology was felt as a threat. 


\section{The historical background}

In the beginning of the 19th century, when the Napoleonic Wars were followed by political restoration, Germany re-established its multi-state system. Only a few of the reforms of the Liberation Wars remained in force; the Stein-Hardenberg Reforms, in particular, were hardly affected. But the bourgeoisie did not receive the promised share in political responsibility. Only in some minor German states were parliaments set up so that they could be called constitutional monarchies. This was still the political situation in the first phase of railway development. The few political changes that did take place, while containing the seed for substantial future changes, did not actually affect the political balance of power at the time. But they affected the chances of the railways. Especially the foundation of the "German Zollverein" in 1834 must be mentioned here. Though this simply meant that many of the German states (with the important exclusion of Austria) adopted the Prussian trade and customs regulations ${ }^{3}$, a market big enough for a substantial growth in trade and commerce was created. Apart from that, the nationalistic liberal movement that ended in the suppression of the 1848 revolution and the enfranchisement of all three classes was important, as it helped to increase especially passenger traffic within Germany.

When the idea of building railways arose, the governments found themselves in a dilemma with respect to this new means of transportation. On the one hand, it was clearly seen by most officials that railways were a very efficient or even necessary way to improve the economic situation and the competitiveness of the country - and hence it was a way to raise states' revenues. On the other hand, the spreading of the railway network had two important disadvantages: first it contributed to the wealth and power of the bourgeoisie who built it because the absolutistic governments did not have the money and were unwilling to borrow it because of the political obligations attached. Secondly, the railways improved the mobility of the people and therefore the diffusion of new ideas beyond a point still regarded as tolerable. This is why early on the Prussian King Friedrich Wilhelm III did not even permit the privately financed building of a railway. Later most states and their monarchical governments publicly supported the idea of building railways, but in fact often worked against their actual construction ${ }^{4}$. 
Figure 2:

THE DEVELOPMENT OF THE GERMAN RAILWAY NETWORK $1842-1913$
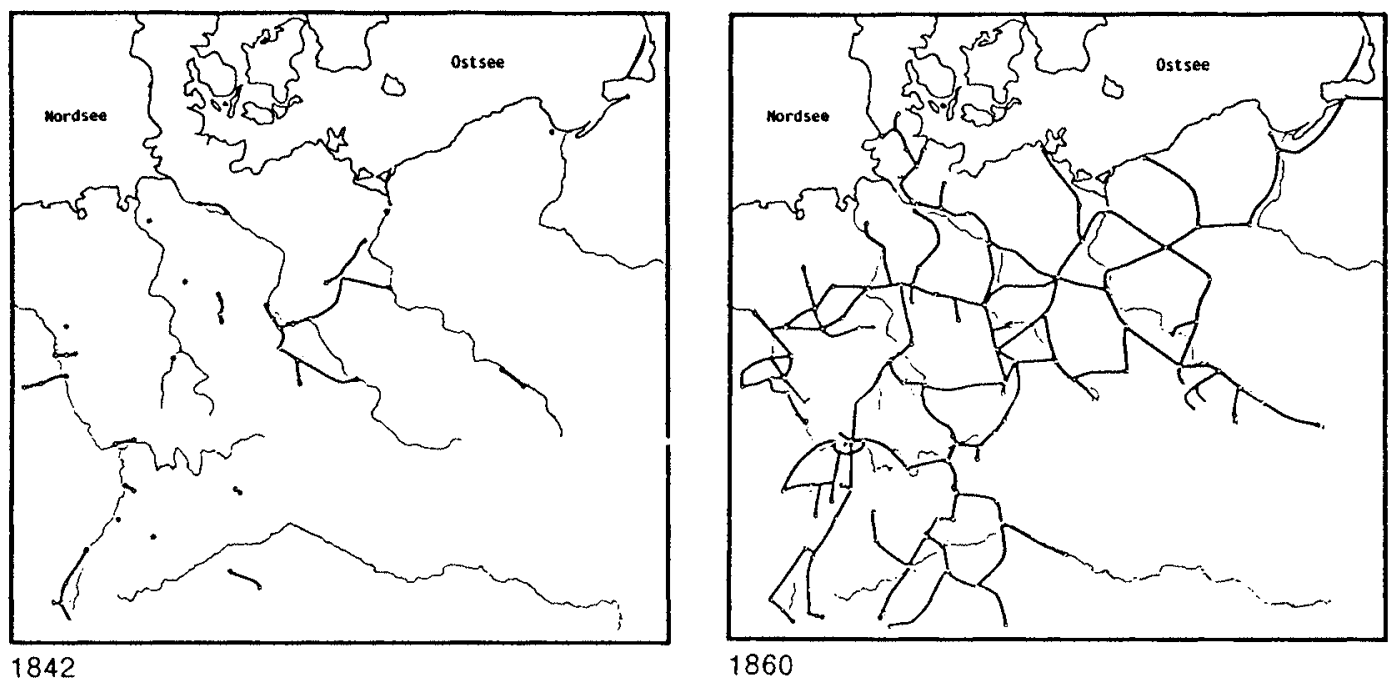

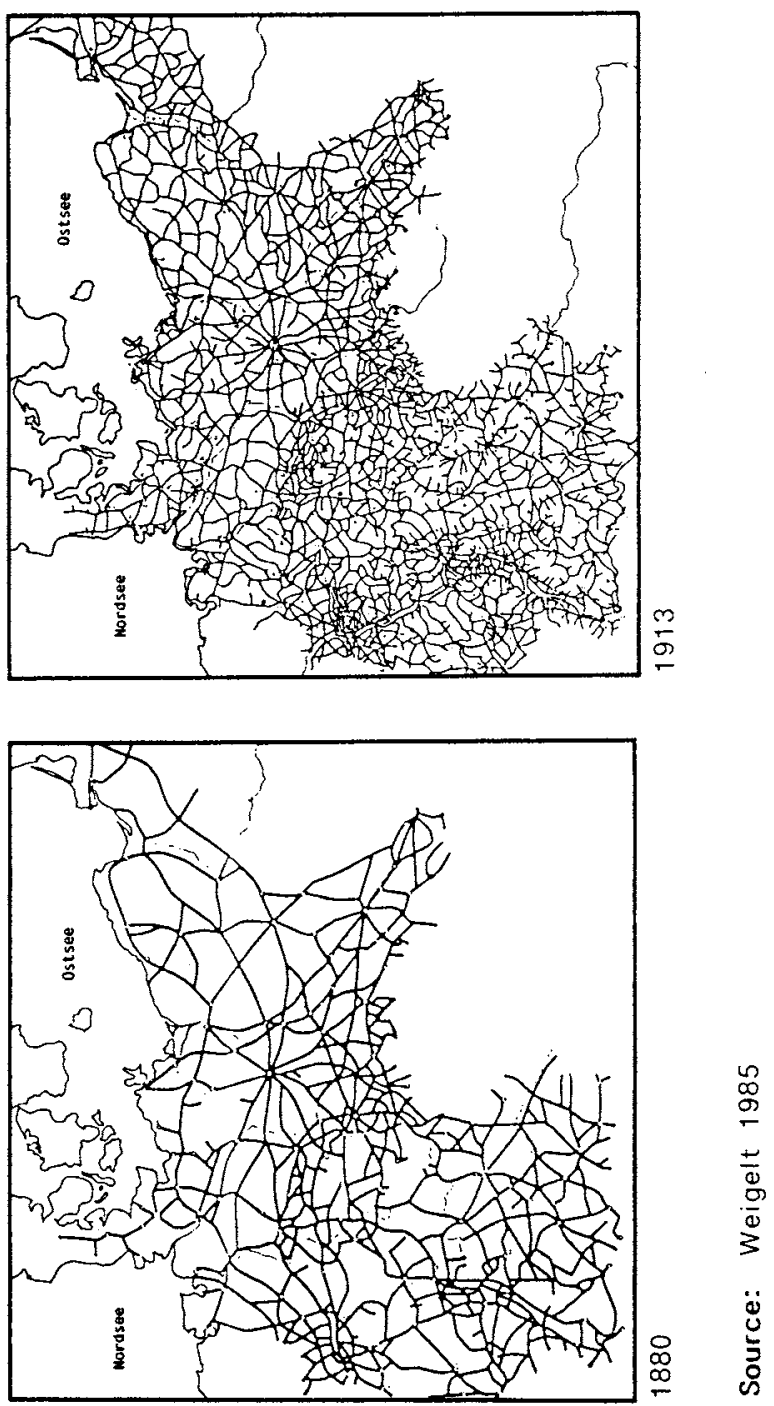
The fact that the railways, despite many obstacles, actually spread in Germany with a time lag of only 10 to 15 years as compared to England shows that other - mainly socio-economic and technical factors were favorable to such a development.

While the political framework stayed quite static, the economy, transportation technology, and technical development generally were undergoing rapid changes, creating pressures for structural adaptation. Until the 1830 s, the German economy was clearly dominated by agriculture, with up to $80 \%$ of the workforce engaged in food production. Only in Saxony and in the Prussian Rhineland was a majority already engaged in trade and manufacturing. But even there, manufacturing took place in small plants with few workers and modern machinery was based only on a very small scale usage. From today's point of view the use of steam power is regarded as the symbol of industrialization. But the few German steam engines - not even one tenth of the number they had in England - were mostly used for water pumping, especially in the coal and salt mines but also in factories which had water powered machinery.

In England the use of machinery and steam engines, together with modern forms of management and production organization, led to an immense increase in productivity and consequently to a decrease in the prices of products. The German craftsmen therefore could not compete with the British factories, even more so as the influx of British goods was not really hindered by taxation during the first years after the end of the "Blockade of Britain". The introduction of large-scale production in Germany after the 1830s was mainly based on two factors: the introduction of foreign methods of mechanized manufacturing and the introduction of new ways of financing which led to the founding of joint-stock companies. In order to raise the required capital these companies offered shares to the public. This method was originally used by the trade companies engaged in trade with the West and East Indies. But in these companies the share-holder also had to account for the losses of the company. The first modern joint-stock company enabled the shareholders to share the companies' profit, but limited the risk to the value of their share. In Germany such a company was founded for the first time to finance a coal railway, where the wagons carrying coal were drawn by horses.

Technological development during this time was generally characterized by the shift from medieval technologies based on water-powered 
wooden machinery to modern ways of production using steam-engines and advanced machinery. Along with improvements in the iron, steel and mining industries, German mechanical engineering developed. The most important factors in this development were the rising level of general education, and the installation of model factories with advanced foreign technologies. The educational reform policy led, among other things, to the foundation of the first German technical universities in Prague in 1806 and in Karlsruhe in 1825. In Prussia the "Königliche Gewerbeinstitut" was founded in 1821 in Charlottenburg near Berlin (this later became the "Technische Hochschule"). This kind of modernization was supported by the government ${ }^{5}$. Prussia, the most important German state, was large enough to need a bureaucratic administration and it employed many modern, economically thinking professionals.

\section{Rising transportation demand and the difficult search for a niche}

The now growing industrial production with its even faster growing demand for transportation revealed the weakness of the existing transportation system. Besides the trading companies, which were traditionally interested in good transportation facilities, the management of the heavy industries was now interested in improving the transportation sector.

During the Middle Ages it was above all improvements in vehicles that maintained or even enabled the increase in the volume of transportation. ${ }^{6}$ Paved roads in general did not exist. Only at specific locations, e.g. river crossings, swamps or mountain slopes, was construction work regarded necessary. Together with the development of national economies in Western Europe, the 18th century saw the first nationwide road building since the Roman Empire in Europe. The importance of good traffic connections as a prerequisite for the development of a nation was realized especially in multi-state Germany. In 1779 Christian von Lüder demanded a network of high quality roads connecting all the important cities of central Europe. Interestingly, this plan asked for "Chaussee" connections very similar to the later network planned for railroads by Friedrich List ${ }^{7}$ to promote a unified Germany. They are also almost identical with the 20th century plans for the Reichsautobahnen. None of the three networks was actually built on the basis 
of these plans. Only independent connections were built, due to the influence of state and local particularism, the importance of profitability as a criterion and, in the case of the Autobahnen, because of strategic planning. Nevertheless, over time the networks evolved to a state surprisingly similar to the one originally conceived.

Despite the fact that new roads and canals were built during the time of Mercantilism and especially during the Napoleonic occupation, traffic connections as a whole were not in a good shape. This became obvious when the demand for transportation facilities increased in the $20 \mathrm{~s}$ and $30 \mathrm{~s}$ of the last century. Nobody doubted the need for an improvement of the transportation system, but as nobody could predict that the increasing demand for transport would continue, the need for a completely new transportation mode was not evident. For most people improvements of the waterways, the roads, the vehicles and of the traffic organization seemed to be more than sufficient to meet future demand. This clearly worked against speedy railway development. As late as 1834, a canal was chosen to connect the Danube and Main. Besides the advantage of the canal for transporting timber - Bavaria's most important export product of that time - the people responsible for this decision had two main arguments against the railroad. First mistrust in the reliability of the new machinery, and secondly disbelief in a steadily growing demand for transportation. ${ }^{8}$

Furthermore the power of steam engines could be used more easily on waterways than on land. In those days steam engines were quite big and heavy and needed huge amounts of coal, and it was much easier to put this additional weight on a boat than on a wagon. Therefore, as early as 1816 a steamship was used for a shuttle service by the Prussian Post Office between Berlin and Potsdam. Steamboats started to operate on the Rhine in 1822 . They became so successful that in 1830 the "Rheinisch-Preußische Dampfschiffahrtsgesellschaft" alone had 27 steamships in service between Köln and Mainz.9

Nevertheless, the larger part of the investments in traffic infrastructure went into highway building. The improvement of these new roads was so remarkable compared to the old ones that they were called "artificial streets". In the three years from 1805 to 1807 , more than $5,000 \mathrm{~km}$ of highways (Chausseen) were built or improved in Bavaria, and in Prussia the length of the highways doubled between 1830 and 1848 to $15,000 \mathrm{~km}$.

The improvements that followed from these measures (and especially 
from the improvements in traffic organization) were quite considerable. Cargo as well as passenger and mail transportation time was greatly reduced and capacity rose in the same manner. ${ }^{10}$ It can therefore be said that there was no general or even national interest in a railway system when its building began. Beside the more visionary imaginations of some poets and scientists, there were only the local interests of tradesmen and manufacturers in different cities who wanted the railroad for improving communication and transit of their goods which could not be achieved by other means.

The first article on a (planned) German railway was published in 1825 and was written by the entrepreneur Friedrich Harkort. Although he first described the advantages of a railway connection between the North Sea and the Rhine (to avoid the Dutch Rhine customs), his true intentions lay elsewhere ${ }^{11}$. In Wetter by the Ruhr he had founded a factory (the later DEMAG) with imported English machinery and English workers. The connections to the nearby coal districts were very poor. Coal was even transported on horseback. Therefore he wanted to improve the transport of coal from the mines to the "Bergisch-Märkische" industrial district. Because of his initiative a test railway using the Palmer principle and horsepower was built in Elberfeld in 1826. This one-rail track was followed by several - now two-tracked railways in the Ruhr Region that connected coal mines with neighboring cities. ${ }^{12}$ Their length was usually only a few kilometers, but on these railways one horse could pull more than a tenfold of an ordinary carriage. Similar to this case, also in the other regions it was individuals who pushed the idea of railways forward ${ }^{13}$, and quite often projects became delayed (or even suspended) because of the death of one man.

At the beginning of the $1830 \mathrm{~s}$, railway projects had sprung up in nearly all major German cities. ${ }^{14}$ Generally these projects were advanced by citizens who intended to improve their city's position in the economic competition with other cities. The promotion of the railway as a system was not the intention of these system-builders.

Beside these entrepreneurs who were only interested in one particular railway line, Friedrich List (1789-1846) was obviously the only man with a great plan and with an understanding of the whole system ${ }^{2.5}$. He failed because he did not adjust to this disjointed incrementalism. A design for Germany as a whole was also doomed because general interest was lacking. For many reasons List was an outsider. As a self-made man with liberal ideas, not rich enough but with a hot temper, 
he did not belong to any social group of political influence. The nobility called him a "revolutionary", the merchants "office-hunter" (Postenjäger) and the academic establishment "agitator". His personal tragedy was that he functioned as a catalyst without reaping any personal benefits. His efforts to see Germany as a whole are comparable to our attempts to think European. Fixed on his aim, he even opposed "small steps" that were improvements of the status quo; he did not understand that complex systems have to prefer evolution to revolution because big steps lead to extreme rates of change in other subsystems and thereby endanger the whole system. Not supporting incremental changes, List in fact played into the hands of the reactionaries. The result was not a grand solution, but a lagging disjointed incrementalism of German railway development. The great names of German railway history are all names of losers. Looking backward, von Baader had invented the wrong system, Harkort went bankrupt and List committed suicide ${ }^{16}$. Later, however, the decentralized network structure proved to be an advantage. According to the unanimous judgement of regional scientists, German particularism led to less regional disparities and higher structural adaptability, lowered the costs of regional policy measures and improved social consensus.

4 Early railway construction: The effects of technology transfer, capital needs, and state regulation

The early technological development in the transportation sector abroad gave Germany the advantage of being able to adopt complete, proven and functioning systems which had already passed their teething troubles. The most influential model was the technologically and financially successful railway between Manchester and Liverpool which opened in 1830. One highly significant consequence of this mode of innovation by transfer was the introduction of the standardized gauge ${ }^{17}$. Only the state railway of Baden used a larger gauge (which was probably better suited for the flat Upper Rhine Valley) in the beginning, but changed to the standard in 1855. But technology transfer also had disadvantages. The English systems were considered to be in optimal shape and improvements were not thought possible ${ }^{18}$. The plans for the 
capacity and the routes of the early German railways therefore reflected the state of technology England had achieved several years before.

In this context, the famous "Ludwigs-Eisenbahn" between Nürnberg and Fürth was not the symbol of unique pioneer work in the new technology. Two years before its opening, the railway had only been one of many projects, but luckily it was finished very quickly. The society promoting this railway, the Nürnberg-Fürther-Eisenbahn-Gesellschaft, was founded in the fall of 1833, it got the concession on February 19, 1834, and it opened only one and a half years later (1835). The advantage of the Ludwigs-Eisenbahn was that all obstacles that usually delayed the realization of such projects could be overcome quickly. Both city councils were in favor of the project and most of the money necessary was provided by citizens. The cost for the complete railway, including locomotive and wagons, was only 122,000 talers (compared to the average of 150,000 to 600,000 talers just for the construction of the same length of infrastructure elsewhere). ${ }^{10}$ The royal privilege that was given with the concession made it even easier to raise the money, especially after the King had bought two shares. The terrain did not cause any difficulties (aside from the question of expropriation); neither bridges nor tunnels were necessary, and all streets were crossed at the same level ${ }^{20}$. Finally there was no competitive organization fighting the project.

All other railway projects in Germany were hindered or even caused to fail by the problems connected with (1) finances, (2) route-finding, and (3) concessions 21 :

1) The financial problem had to be solved first. The amounts of money necessary for building a railway were extraordinarily high. The possible financiers had to be convinced of the success of their investment. In the beginning, this was very difficult because no railway had yet been built in Germany. Besides, profits could only be expected after several years. Therefore many of the potential investors were skeptical about the railway's technical performance and its financial profitability. But this problem was largely resolved when the "LudwigsEisenbahn" was built and when it proved to be economically successful: After its first year, the company paid a dividend of $20 \%$.

2) Routing was not so important when discussions about a new railway started, as most railways were planned as connections between two major cities. But when the actual construction began, many decisions had to be made. Which places between the two cities should be con- 
nected to the railroad? In which part of the city should the terminal be? Where should rivers and mountains be crossed? How could important factories and army forts be reached? How could towns and noblemen who declined to participate be circumvented? These kinds of issues often delayed construction.

3) Though private enterprises constructed most early German railways, the state could refuse to grant necessary elements: the concession, the law to expropriate grounds, and the interest guarantee. The state had a seat and a vote in the administration of the companies. Soon the various state governments realized that they were indispensable to get a railway network which included many necessary, but nonprofitable lines. In spite of this awareness, most German states accepted privately owned railways under strict state control. Requests for a concession where often promptly met, but generally these concessions were tied to a number of preconditions, so that construction work could not start at once. Besides this, the government sometimes promised concessions to more than one party or withdrew concessions because of minor violations of the stipulated conditions.

Many of the first railway lines proved not to be profitable. Railway building became much more expensive than expected. Only Paul Camille Denise, a German engineer who had also built the "Ludwigs-Eisenbahn", could say that all his railways were profitable. He built simple but solid tracks, which meant that the construction costs were relatively high at the beginning, but the long-term operating costs could be kept low. Higher construction costs are soon past and forgotten. Many of the other companies were forced to resort to the interest guarantees of the state.

\section{After a difficult start, a quick take-off}

Due to these difficulties all the other railway projects except for the Ludwigs-Eisenbahn remained in a planning or even discussion stage, until the positive results of the latter became public by 1836 and 1837. From then on, the interest of governments and of investors in railway construction was big enough to push the other projects forward $^{22}$. Within 5 years, from 1837 to $1841,680 \mathrm{~km}$ of railways were opened. The first state railway connected Braunschweig with the Harz 
mountains $(30 \mathrm{~km})$. All the other railways connected nearby cities: Berlin and Potsdam $(25 \mathrm{~km})$, Leipzig and Dresden $(120 \mathrm{~km})$, Frankfurt/Main and Wiesbaden-Mainz (40 km), Düsseldorf and Elberfeld (Wuppertal) $(30 \mathrm{~km})$, Munich and Augsburg $(70 \mathrm{~km})$, Berlin and Frankfurt/Oder $(100 \mathrm{~km})$, Magdeburg and Leipzig $(110 \mathrm{~km})$, Mannheim and Heidelberg $(20 \mathrm{~km})$, Cologne and Aachen $(70 \mathrm{~km})$, Hamburg and Bergedorf $(20 \mathrm{~km})$. Aside from these lines, some extensions were also in progress. These city connections became later the nuclei of the polycentric German railway network.

The railway boom was accompanied by several speculative projects which soon proved to be unrealistic (at that time) and many people lost their money. Often stock-companies were founded and shares sold before the railway got the concession. During this boom the costs of building the railways rose immensely. When the "Westfälische Landtag" allowed the foundation of the "Köln-Mindener-Eisenbahn Company" in January 1831, the $230 \mathrm{~km}$ connection of the rivers Rhine and Weser was estimated at 600,000 talers. In 1836 , when the company was finally constituted, this calculation had risen to 4.4 million. In 1840 it had risen to 5.6 million. When this railway finally opened in 1847 , construction costs amounted to 13 million talers, i.e. about one fourth of the annual budget of Prussia of that time.

The main reason for the delay in the construction of this particular railroad was its length. It was the first railway that was intended not only to connect two cities, but was planned as the connection between two distant rivers, the Rhine and Weser. This railway can thus be called the first German long-distance railway. ${ }^{23}$ It traversed not only densely populated commercial areas, but also rural areas. For such areas it was very difficult to raise any money, because it was not certain whether the railways could find enough passengers and cargo there. During the time it took to realize the Rhine-Weser railway, the pioneer stage of the railroad systems development had ended.

By 1840 the importance of the railroad system as a whole for the nation or the individual states had become obvious. Only one year after the opening of the Köln-Mindener railway, it became the center part of the first transnational railroad from Frankfurt/Oder to Aachen (with connection to Belgium). Although Prussia adhered to the concept of privately owned railway companies for another 40 years, the companies now came under very strict state control. Except for Prussia and Saxony, all the other states in Germany now decided to build 
and operate railways themselves - without necessarily taking over or prohibiting all privately owned railways. At the beginning of the $1840 \mathrm{~s}$ the German states made plans for their railroad networks. These plans were no longer dominated by the potential traffic between two points. Some states planned railways in order to influence the international trade routes - or in fact to take them away from the other German states' territory. ${ }^{24}$ One of the main aspects of railway planning was now to extend the accessibility to all provinces to give them better chances for economic development. But despite these official plans, the main reference point - where to start building railway - was the existing traffic. Therefore it took only ten more years to finish a skeleton of railway tracks in Germany. In 1855 Germany had about $7,500 \mathrm{~km}$ of railroads. These lines followed traditional traffic patterns of the last thousand years and corresponded very much to the road network plan of Lüder, or to the railroad plan from Friedrich List.

Although the main purpose of building the railways had been the transportation of goods, in the 1830 s and 1840 s they primarily attracted passengers. The manner in which the railroad network was developed made it very difficult to attract cargo. Most railways opened operation before they got to the final destination, usually when the nearest town was reached. Beside the fact that long-time treaties between merchants and haulers quite often forced shippers to use road transport, there was also the problem of having to transship the cargo between different lines as well as between different transport modes. As long as the railway could not cover the whole transportation route, repeated reloading often took more time than the supposedly fast railway saved. In contrast to cargo, passenger figures soon exceeded their predictions by far. The predictions were based on the number of people then using the carriages between the cities where the railway was planned. Most of the additional passengers were former pedestrians, belonging to a social group that did not use public transport before, mostly because it was too costly. Riding carriages was hardly faster than walking. Suddenly by using the railway one could save so much time that one could get to the next town, have one's business done and return the same day. So even those who usually walked could save money: The price for a $30-\mathrm{km}$ return ticket was 2.40 marks in third class and only 1.60 marks in fourth class, which is less than what one usually had to spend for lodging and eating, not considering the one day saved for working and the cost for shoes and clothing. ${ }^{25}$ 
The development of the regular passenger transport to such an unprecedented and unpredicted degree is one of the best examples of the difficulties of future oriented technology assessment ${ }^{26}$.

In cargo transportation the importance originally conceded to general cargo was very soon displaced by bulk cargo. But in order to compete with the water-transport for this kind of cargo, two more developments in the railroad system had to happen ${ }^{27}$. On the one hand the price of cargo carriage had to drop almost to the level of water-transport, and on the other hand the capacity of the railways had to be increased in order to match the amounts of cargo the increasing industries demanded. These developments cannot be seen in a network map.

Most of the coal used in Germany at the time came from England and was carried by boats at a rate of about 1 taler-pfennig (i.e. one hundredth of a taler) per ton kilometer. As the railway companies did quite well with the existing passenger and cargo transportation, they saw no necessity to reduce their freight rates, which were about 10-15 taler-pfennigs per ton kilometer. Due to the involvement of the Prussian Secretary of Commerce, August von der Heydt, and because of a cooperation among the coal mines in Upper Silesia, the railway company serving this area in 1849 offered the first one-pfennig-tariff train to Berlin. Within a few years these cheap trains that carried only coal which was an innovation as well - became one of the main source of revenues. The share of hard coal in the cargo transport volume of the Prussian railways rose from $1 \%$ in 1850 to $14 \%$ in 1860 and to $31 \%$ in 1875 . The total coal transport in Prussia reached $1,012.8$ million tkm in 1865 (45.1\% of the total cargo transportation) with a freight of 37.2 million marks (29\% of the railways' cargo revenues) ${ }^{28}$. In other words: although they did not recognize this in the beginning, it was the railways themselves that induced the low value mass transport demand they were best suited for.

Yet reasonable prices alone were not enough to initiate this development. The railroad network had to be modified to match this rising transportation volume. Even when all major destinations where reached by the railroad, cargo still had to be transshipped. The different lines terminated in the outskirts of the cities. Each line had its own station and even if the stations lay sometimes quite closely together, the lines did not connect. For the passengers, transfer to the next station might have been annoying, but for the cargo this was a real obstacle. Furthermore, most of the first railways were single tracks, and the 
stations along the line were often simply places where the trains stopped, which meant that when stopping at a particular station the complete line was blocked for the time necessary to load and unload cargo.

Long before Germany was covered by a complete railroad network, the improvement of the core network was carried out. In Breslau the stations of the Upper-Silesian railway and the Lower Silesian-Märkische railway were connected in 1850 (this was one of the preconditions for the previously mentioned coal train to Berlin). In the following year the Prussian state built the semicircular Connection Railway in Berlin. Similar connections were built in Leipzig in the same year, and in Dresden in 1852. In Cologne, only in 1859 was the Rhine crossed by a bridge, connecting the Rhine-Weser railway terminal in Deutz with the Köln-Aachen-Antwerpen terminal on the left side of the Rhine.

Meanwhile the established lines were improved to allow for higher speed trains, second and third tracks were constructed, and switches were installed in and between the stations. This allowed the bypassing of faster trains ${ }^{20}$ and facilitated direct railroad connections to factories, or even to agricultural and mining facilities.

\section{The end of the introduction phase}

By the early 1850 s it had become obvious that the railways were utilized to the greatest effect when they enabled cargo transportation without the need to transship. As the railways were so superior to the traditional ways of transportation, long loop-ways (detours) were accepted in order to keep the cargo (or the passengers) on the rail. Although the railroad network of that time covered most of the traditional trade-routes, some connections were still missing. In the first 20 years of railway history several projects had failed because of a specific German feature: Political particularism had produced enclaves and some absurd borderlines, and traffic routes between two cities in one state would therefore have to cross borderlines, but permission to do so was usually denied. That made such railways financially unattractive. But soon the governments saw the importance of interstate and international traffic for the states' own industry and commerce and ensured the future of the railways by treaties. Before, it had taken several 
Figure 3:

MAIN INDICATORS OF THE

OEAMAN AAILWAY SYSTEM'S OAOWTH

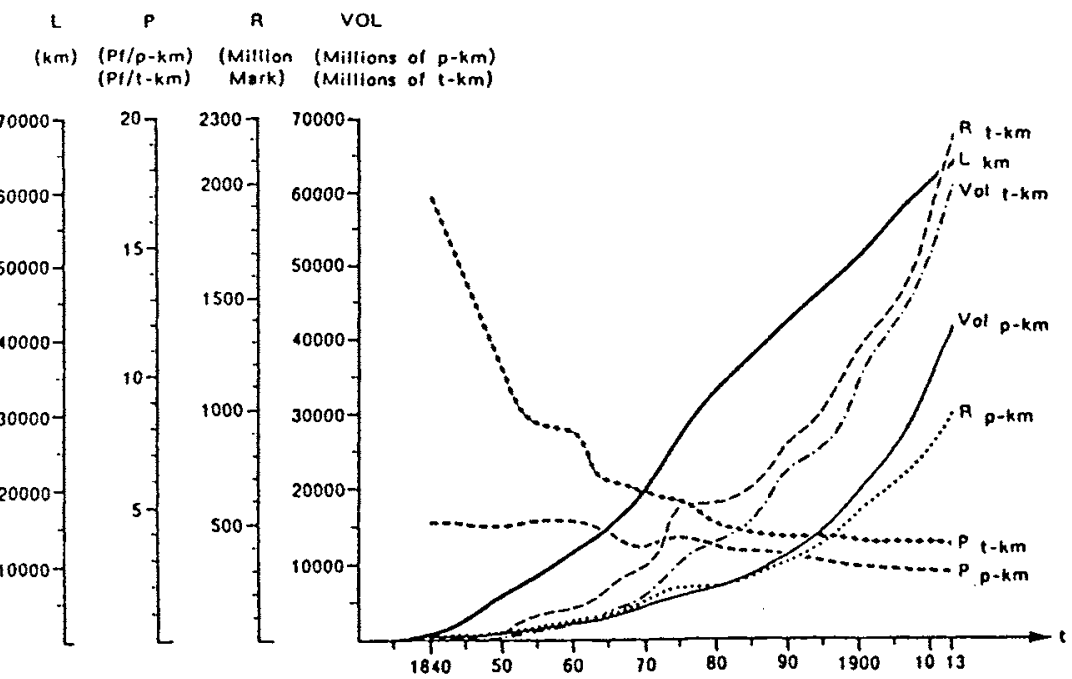

Longth of network (L $\mathrm{km})$

-... Volume of Prolght trellte (Vol $t-\mathrm{km})$

_ Volume of psssenger traffic (Vot $p-\mathrm{km}$ )

- - Revenues from freloht traffic ( $R,-\mathrm{km}$ )

...... Revenues trom passenget traffic $(R, p-k m)$

- + Average price per ton-kllometre (p t-km)

-.-- Average prtce per passenger-kllometre (P p-km)

Source: div-Lexikon, Bd. S, München 1974; Fromding, R.: Eisenbohnen und deutsches Wirtschaftswachstum 1840-1879, Dortmund 1975; Huber, P.: Die deutsche Elsenbahnentwicklung: Wegweiser für eine zukiinttige Fernschnellbstrn?, DFVLA-FE 78-25, K8̈tn 1978; Hendbuch der deutschen Elsenbehnstecken, Moinz 1984; Voigt 1965 
years to reach an agreement between two German states regarding one short railroad. Now within a few years, general treaties between the German states and their neighbors were signed covering traffic connections between their capitals and between important trade centers.

This governmental willingness to improve the railroad network soon resulted in the closing of still remaining missing links. In Prussia the number of concessions granted increased, and in Bavaria the state even allowed private companies to build and operate railways. One important reason for this increase in concessions was probably the intention to intensify competition between the railways; in Germany the state railways played the same role as competitors as the private companies did in Britain or in America. By 1865 all the old trade routes had rail track and each city and mining district could be reached without long detours. The length of the railroad network had reached nearly $14,000 \mathrm{~km}$. In the early $1870 \mathrm{~s}$ more than $1,000 \mathrm{~km}$ of railroads were built annually, and between 1865 and $1875,13,700 \mathrm{~km}$. That is about the length that had been built in the 30 years before.

With this completion of the mainline-network, the integrating stage of the system's evolution had nearly ended. The connections finished during the 1870s had all been planned in this period. It is interesting to note that this integration of the railroad network coincided with the unification of Germany. After the "Reichsgründung" of 1871, two factors led to the further expansion and subsequently to the intensification of the network. For one thing, earlier railway lines had been built from town to town so as to collect as much traffic as possible. This led to remarkably loopy ways for the traffic between the terminal cities. Now, competitive companies established direct linkages between major destinations. Secondly and more importantly, competition resulted in the building of financially doubtful railways into rural areas. However, such lines were built not only out of mere speculation, but also because of the state's intention to grant improved accessibility to every region. So, although the nearly $30,000 \mathrm{~km}$ of 1875 covered Germany with a complete railway network, railway building continued at the rate of about $1,000 \mathrm{~km}$ annually (Figure 4 ).

Quite often railway building was requested by the towns not yet connected. In the wake of industrialization, German towns and communities situated near the railway network which were not yet serviced made strenuous efforts to establish linkages, hoping to help local producers. However, the opposite often occurred. Extension of the 


\section{Figure 4:}

THE PAOVISION OF AURAL TRANSPOAT
B
L O C A L
RAILWAY LINES
A N D

BUS LINES IN BAVARIA I840-1800

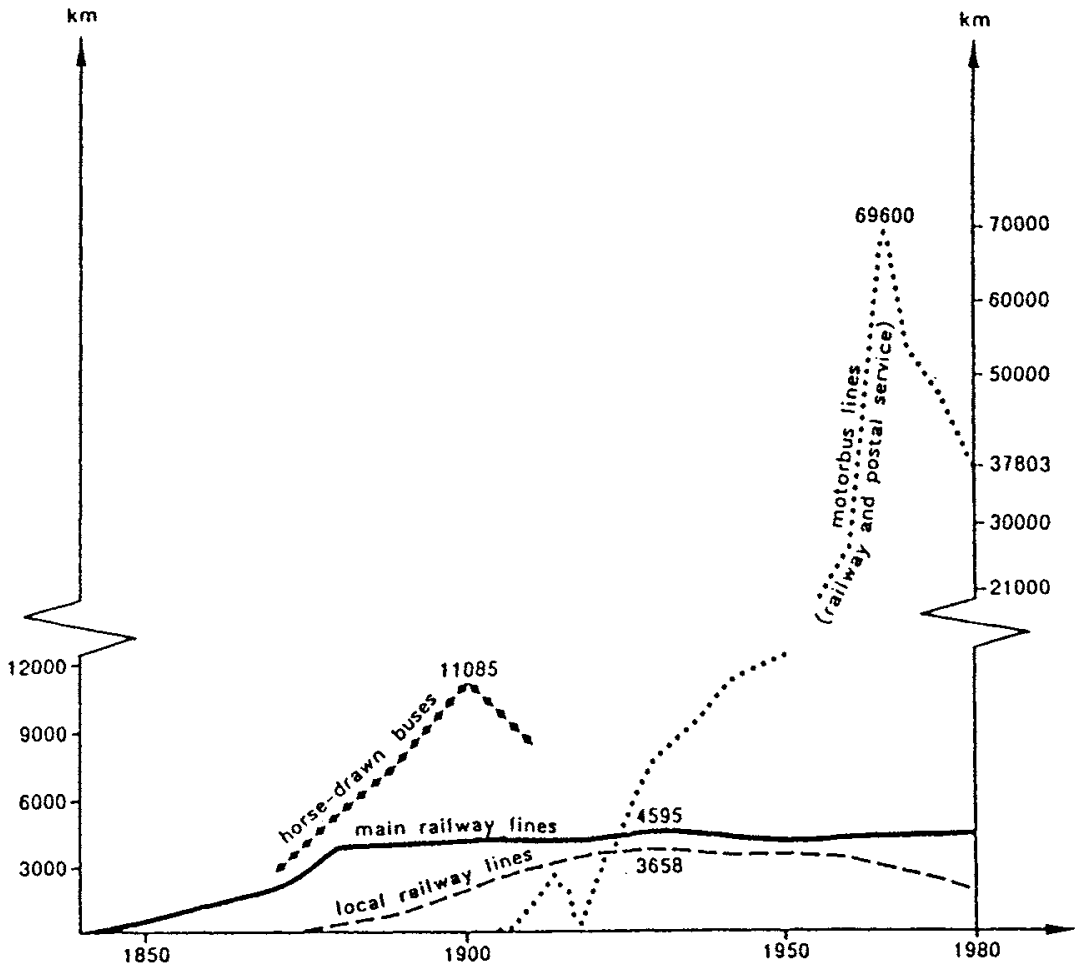

Source: Weigelt, H.: "Oer dffentllche Linlenverkehr in der Fläche - eus der Sicht der Deutschen Bundesbahn"; in: Die Badienung ländichor Rzume elne Aufgabe aller Verkehrsträger; Schriftenreihe der DVWG, Band 864 $K \operatorname{lin} 1983$, S. 84 
railway network of the State of Bavaria to these zones caused an economic decline, whereas the zones of industrial growth continued to expand. Nearly all those production sectors and enterprises in the declining zones which had been mentioned in the petitions as justification for the requested rail linkage were forced out of the market in the long run. Economic development was marked at the junction points of the main lines and at the terminal stations in the towns, where transfer to road haulage was effected ${ }^{30}$.

\section{Nationalization of the railways}

During the intensification stage that followed the completion of the mainline network after 1875 , organizational changes also occurred. This period is characterized by the integration of the public railways, which were juridically and administratively independent, and the private railways to form the "Länderbahnen", i.e. one state railway for each of the bigger German states.

Although nationalization of the railways had been demanded since the beginning, a necessity to do so was never seen by parliaments and governments. Especially the already mentioned pioneers of railway building, Harkort and List, pleaded for state railways in their first papers. After the separate railway companies had evolved in Germany, they gained most of the advantages of a unified railway by voluntary collaboration. Despite their competition, the railway companies had started to cooperate quite early. Already in 1846, ten of the 17 Prussian railway companies of that time founded the "Verband der Preußischen Eisenbahnen". The aim of this association was to standardize the technical equipment, the rolling stock and the overall dimensions of bridges and tunnels so that trains and especially wagons could use the tracks of different railways. Furthermore first regulations for standardized tariffs were discussed. In 1847 all railway organizations in Germany founded the "Verein Deutscher Eisenbahnverwaltungen" in order to extend these standardization efforts, and before it was possible to travel from one side of Germany to the other in the same train, one could make such a journey with several trains but one ticket.

While this system worked very well in peacetime, the disadvantages of such a multicompany railway system became evident during the 
French-German war of 1870-1871. Coordination problems led to delays in troop and material transports. These experiences and the spirit of the newly created German Reich renewed intentions to unify the railways as well. But similar to the case of the German trade policy at the beginning of the century, a coalition of economic liberalism and political particularism obstructed a solution for Germany as a whole. To prevent the possibility of a Prussian dominated German state railway, the medium sized states of Bavaria (1875) and Saxony (1876) nationalized all important railways in their territory. Prussia, and here first of all Bismarck, therefore concentrated unification plans on Prussia's own territory and on small neighboring states. Until 1887, Prussia bought all private railway companies that operated main lines in its territory.

This polycentric concentration process excluded only small private companies that served secondary lines of local importance. At the turn of the 20th century, $59,082 \mathrm{~km}$ of the $63,794 \mathrm{~km}$ of German railways belonged to 8 state railways. These states were Prussia, Hesse, Saxony, Bavaria, Württemberg, Baden and the small but opinionated duchies of Oldenburg and Mecklenburg-Schwerin.

When the railway had reached this heyday of its development, it was not just a new means of transportation with a higher capacity. It had become a new dimension of space- and time-bridging ${ }^{31}$. The railways became the necessary precondition of economic development and proved to be very profitable themselves. The annual revenues of the 8 state railways averaged more than 1,000 million Reichsmarks at that time.

Because of its importance, the railway was strongly influenced by world politics. It was a direct result of defeat in the First World War that a national railway company was finally founded in 1920 . Forced by the peace conditions of the allies and the new constitution, the "Länderbahnen" were unified to the "Deutsche Reichsbahn". As the new German Republic could not afford to take credits that were necessary to rebuild the damaged railways, the state-owned "Deutsche Reichsbahn" was converted into a legally, administratively and financially independent company, the "Deutsche Reichsbahngesellschaft". ${ }^{32}$

Besides paying off its own debts, this company was forced to produce 600 million gold marks (i.e. about 150 million gold dollars) annually to redeem German reparations to the Allies. In the years from 1925 to 1932 the Deutsche Reichsbahn paid 4.18 billion gold marks, although 
in 1928 for instance it still had to make repair investments that added up to 2.5 billion Reichsmarks. So, at the beginning of the final stage of its development, the railway not only faced the competition of a new transport technology (i.e. the automobile), but also severe financial problems.

\section{Summary and conclusion}

Much as in the introduction of other new transportation systems, the railway had to face the strongest opposition in its initial phase. The groups that opposed the railway stood to lose what they had achieved with the old and well-known technology. The first supporters of the railways therefore pointed out the advantages of the railways for the extension of agricultural production and for accessibility to the spas (like Baden-Baden). As the Postmaster General opposed most of the early railways, mail had to be carried without payment and the railways had to compensate for the losses of the mail coaches. Because of these obstacles and because of the dominating influence of the traditional technologies (especially inland navigation), the railways found their first employment in niches or when really no other means of transportation was appropriate. As the introduction of the railway took place during a period of general growth, the limits of the old system's capacity became evident. Other favorable conditions were the maturity of the new technology at the right time and the personal engagement of open-minded entrepreneurs - men who were familiar with the new technology, convinced of its success, and who had the economic and political knowledge to push its introduction (Figure 5).

After the railway had been introduced and had shown its operational abilities, other cities and states reproduced it in manifold ways. Because of this, the railway could extend and at the same time modify the system, i.e. the growth of the new technology actually enabled the structural changes that had become necessary. When the railway had become the dominant transportation system in the $1870 \mathrm{~s}$, its field of operation spread over the whole transportation sector. Because of its superiority compared to other transportation modes and its economic success, railways were built to almost every town and were used for nearly every transport purpose. This dynamic mechanism of success 
Figure 5: THE GERMAN CASE: A SIMPLIFIEO MODEL OF RAILWAY DEVELOPMENT

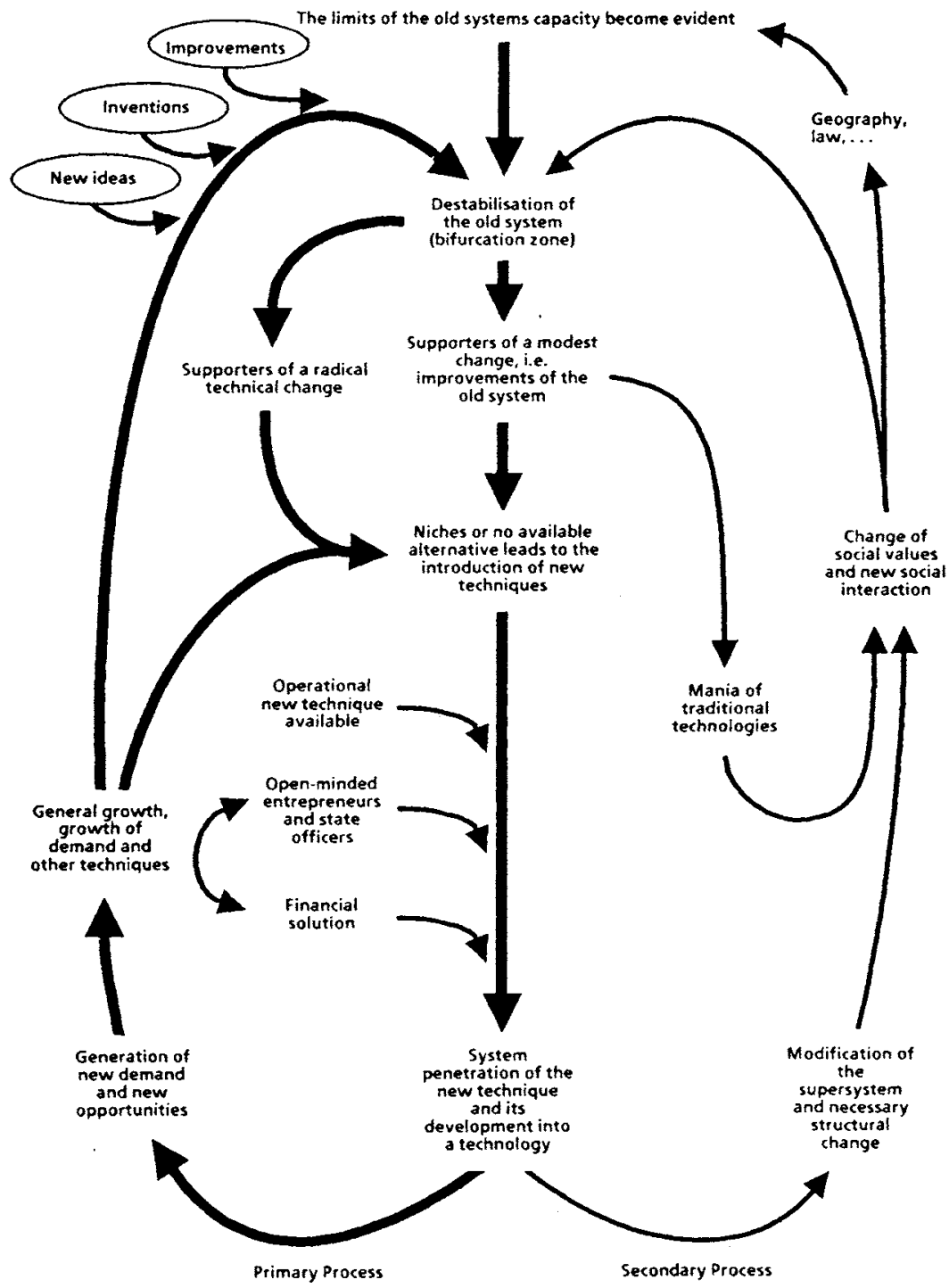


can be represented as a four-step acceleration process: (1) the existing system reaches its capacity constraints; (2) a new technology is at hand; (3) improvements of the old technology and isolated usage of the new technology increase demand for transportation; (4) this additional demand allows the full engagement of the new technology (Figure 6).

Figure 6:

THE DYNAMIC MECHANISM OF SUCCESS

Systems complexity

(capacity,

demand)

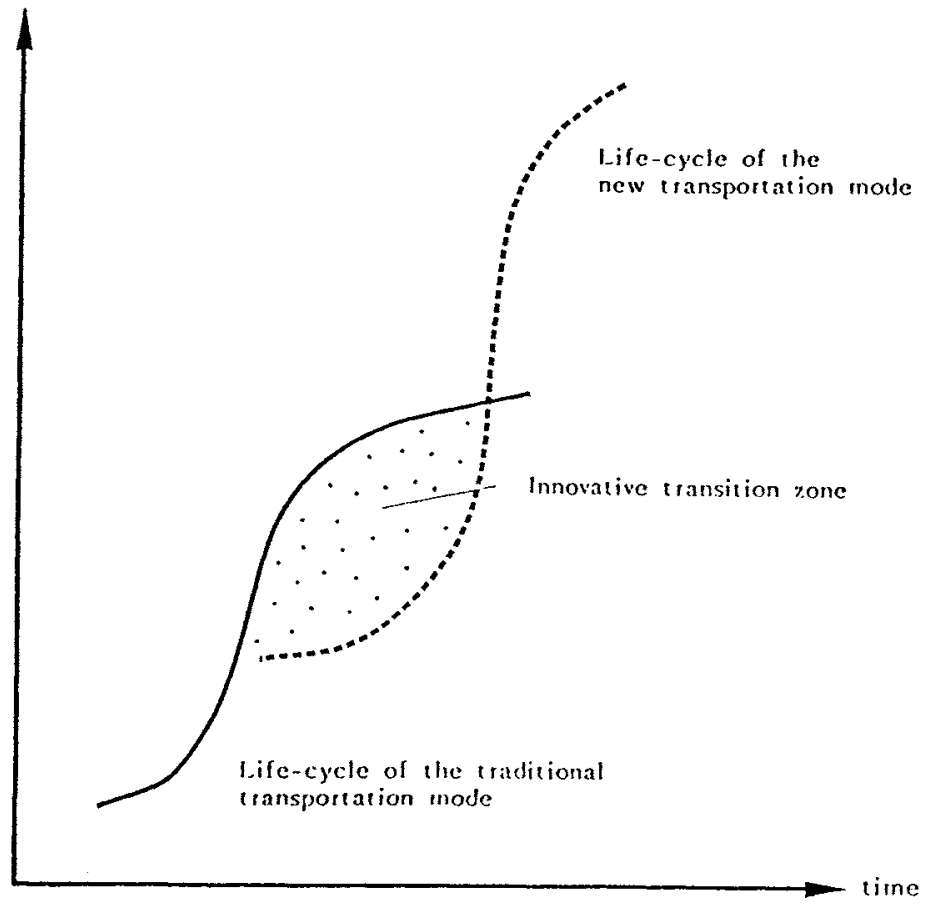


After another 70 years and after the diffusion of the automobile, the railroad network that is used by the Deutsche Bundesbahn today is very much the same as that part of the network that had existed at the end of the demand-oriented construction stage.

The rise and fall of the German railway system suggests some interesting conclusions. The growth of urban agglomerations and conurbations was connected with the building of the railway system. A by-product of this spatial differentiation was the creation of "the rural areas". When the main lines had been built, the search for new investment opportunities for rail products, together with considerations of regional equity, stimulated further extension. Because no better means of transport was then available, the feeder rail network had to fill the gap. This decreased the profitability and efficiency of the whole network, but the transport monopolist of that time could afford it. However, the need for a more flexible and faster low cost solution for areas of low demand was now felt. To provide everybody with a private siding was beyond the abilities of the railway system; the highest network density was reached when $75 \%$ of the villages were accessible by rail. Thus a niche opened up for the automobile.

A critical point was reached in the 1920s when the railways came under competitive pressure from road haulage. Caught in a world of railway thinking, the policymakers and their advisers were unaware of the different quality and cost profiles of this newcomer. They also underestimated the structural changes in general transport demand. This miscalculation was portentous because the increasing percentage of high-value goods favored the lorry. The political solution (besides licensing) was to tie the prices of road freight transport to the high tariffs of the railways. This meant that the railways were not compelled to concentrate on the market segments they were especially suited for. On the contrary, these political measures fed the dangerous illusion of being still the general national carrier. The result was inevitable: the high prices enabled the road haulers to challenge the railways on their own ground. The high prices not only shifted the high value goods to the road, but the high profits enabled the road haulers to compete with the railway in the market for low value mass-product transport between industrial and commercial premises where a substantial volume of traffic originates or is discharged. In the 1950s, railway managers were ready to lead their state enterprise like a private business. But the "Rail Act" remained unchanged and forced the railways 
to continue behaving as a general means of transport. Whereas the road and its transport got nearly everything it wanted from legislators, the railroad did not. The end of the story is well-known.

Notes

1 Similar stages of railway development can be found in: T. Haberer, Geschichte des Eisenbahnwesens. Wien, Pest und Leipzig: A. Bartleben, 1884; G. Riegels, Die Verkehrsgeschichte der deutschen Bisenbahnen. Elberfeld: Baedeker, 1889; H.-P. Schäfer, Verkehr und Raum im Königreich Bayern rechts des Rheins, Habilitationsschrift, Universităt Würzburg, Würzburg, 1982 (Manuskript); H. Weigelt, Epochen der Eisenbahngeschichte. Darmstadt: Hestra, 1985.

2 The profitability of this feeder network was doubted by its critics already during its construction.

3 The plans for a unified German customs system, which was in fact demanded by the "Deutsche Bundesakte" (a kind of constitution for the German Confederation) in 1815, failed because of the particularism of the German states. During this time of debate over the German unification Friedrich List became well-known in Germany because of his fight for liberalization and against custom barriers inside Germany.

4 W. Lotz, Verkehrsentwicklung in Deutschland 1800-1900. Leipzig: Teubner, 1906; F. Schnabel, Deutsche Geschichte im 19. Jahrhundert, Vol. 3: Erfahrungswissenschaften und Technik. München: Deutscher Taschenbuch Verlag, 1987 (first 1934); B. Stumpf, Geschichte der deutschen Eisenbahnen. Mainz, Heidelberg: Hüthig und Dreyer, 1961; H.v. Treitschke, Deutsche Geschichte im 19. Jahrhundert. Leipzig: J. W. Hendel, 1927.

5 The Prussian state even financed journeys to England for young engineers so that they could obtain (i.e. spy) the "know-how" of railway building. The intention was economic development by import substitution.

6 Especially the horse-collar and the wagon tongue increased the capacity of horse drawn carriages. Beside this the capacity of the sea going vessels rose from around 100 tons at the turn of the millennium to about 1,000 tons at the end of the 18th century. Improvements in the technology of canal building enabled an extension of the then superior water transport. (F. Braudel, Sozialgeschichte des 15.-18. Jahrhunderts. München: Kindler, 1985).

7 A. Birk, Die Straße. Karlsbad: Adam Kraft, 1933; F. List, Über ein sächsisches Eisenbahnsystem als Grundlage eines allgemeinen deutschen Eisenbahnsystems. Leipzig, 1833; F. List, Das deutsche Bisenbahnsystem als Mittel zur Vervollkommnung der deutschen Industrie, des deutschen Zollvereins und des deutschen Nationalverbandes überhaupt. Stuttgart, Tübingen, 1841. Both published in Friedrich Lists gesammelte Schriften, Ed. by L. Häuser, Th. 1-3. Stuttgart, Tübingen: 18501851. The historical importance of List's plan is its design for a region of several 
independent states. He foresaw the abilities of this new technology as a tool for the unification of Germany.

8 The procedure of this decision finding is described in great detail by H.P. Schäfer, "Die Entstehung des mainfränkischen Eisenbahn-Netzes", Würzburger Geographische Arbeiten (1979) 48.

9 In 1838 the Hofrat G. Muhl from the Duchy of Baden wrote a booklet about the advantages of the railroads. In it, he described a future European railway network that was to bring the world trade from the seaways back to Germany. But for the distance between Köln and Mainz he kept the steamboats. (G. Muhl, Die westeuropäischen Eisenbahnen in ihrer Gegenwart und Zukunft. Karlsruhe: G. Braun'sche Hofbuchhandlung, 1838.)

10 The improvements that were possible become obvious when one considers that the introduction of express carriages alone reduced travel time between Frankfurt/Main and Stuttgart from 40 hours in 1821 to 25 hours in 1822; K. Beyrer, "Das Reisesystem der Postkutsche-Verkehr im 18. und 19. Jahrhundert" in Zug der Zeit - Zeit der Züge: Deutsche Eisenbahnen 1835-1985, Vol. I. Berlin: W.J. Siedler Verlag, 1985, pp. 38-59.

11 W. Klee, Preußische Eisenbahngeschichte. Stuttgart, Berlin, Köln, Mainz: Kohlhammer, 1982.

12 As these railways were copies of the old English wagon ways with flat bar iron on wooden beams and with additional flange wheels they cannot be regarded as the first real (i.e. modern) railways (Weigelt 1985, op. cit., p. 25).

13 Friedrich Harkort's brother Gustav was involved in the building of the DresdenLeipzig railway and was its first president for 30 years.

14 Schäfer (1982, op. cit, p. 359) cites a list of 17 railway projects that was published by the "Central Verein für Eisenbahnen" in Kassel, 1835.

15 There were others who designed railway plans for Germany at that time as well, e.g. Weigelt (1985, op. cit.,) shows a plan by Grothe from 1834, but these men did not find any publicity at all.

16 See: Schnabel 1987, op. cit., p. 330-393; W.O. Henderson, Friedrich List. London: Frank Cass, 1983.

17 The underdevelopment of German industry and therefore the necessity for all German railway companies to buy their first locomotives in England was the simple reason for the uniform use of Stephenson's $1435 \mathrm{~mm}$ gauge. In England it had already become by far the most common one.

18 The first German railway committees usually asked British experts for judgments about their plans. For the first German railway Paul Camille Denise had planned a gauge of $1,420 \mathrm{~mm}$ and already started to build it. The necessity to use an English locomotive forced him to change it. The British superiority went so far that this first German steam-locomotive was also put together by an Englishman who later on even drove the train and became a very respected citizen of the city of Nürnberg.

19 Riegels 1889 , op, cit., p. 2.

20 Paul Camille Denise had wisely planned low long-term operating costs for this railway. That he could realize his aim, with the exception of the gauge (see Note 18), and did not copy the more advanced example of the Liverpool - Manchester railway, was one of the reasons for this railway's economic success.

21 The weakness of German industry could be cited as a fourth factor. Several projects got delayed because domestic industrial products could not be delivered in time or broke during construction. 
22 J.C. Bongaerts, "Financing Railways in the German States 1840-1860 - A preliminary view", The Journal of European Economic History, 14(Fall 1985)2, pp. 331-345.

23 There were two other railways longer than $100 \mathrm{~km}$ in Germany before the CologneMinden railway. The "Linz-Budweis railway" connected the rivers Moldau (Elbe) and Danube already in 1832 with a length of $131 \mathrm{~km}$. It is not considered here because horses were used to pull the wagons. Another reason is that its construction did not even allow steam engines. So already in 1859, parts of it were removed and in 1874 the complete line was closed (G. Kleinhanns, "Die LinzBudweiser-Bahn - Ausgangspunkt des internationalen Schienenverkehrs", Oberösterreichische Heimatblätter 36(1982)3/4, pp. 250-259). Also about 1840 Dresden was connected with Leipzig and Leipzig with Magdeburg. But this $230 \mathrm{~km}$ link was not designed as one railway.

24 An inherited belief from the middle-age road policy was to keep through traffic as long as possible on one's own territory, mainly for financial reasons and for the sake of wheelwrights, innkeepers and postmasters. Railheads were not only built because of the multi-state system. Another reason was the belief that changing trains and/or shifting cargo were good for the local economy.

25 Riegels 1889, op. cit., p. 27.

26 E. Jochem, "Hilfen und Irrtümer beim Rückgriff des Prognostikers auf die Vergangenheit", VDI-Technikgeschichte, 51(1984)4, pp. 263-275.

27 During the first two decades the railways did not intend to compete with water transport. Therefore in Northern Germany with its south-north going rivers mostly East-West connections were built. Railways that connected two cities at the same river tried to avoid the river valley. F. Voigt, Verkehr, Vol. II: Die Entwicklung des Verkehrssystems. Berlin: Duncker und Humblot, 1965.

28 W. Klee 1982, op. cit., p. 96.

29 The reduction in travel time between major destinations was achieved to a much greater extent by shortening the waiting time at the stations on the way or even by passing them, than by rising the speed of the trains (Voigt 1965, op. cit.).

$30 \mathrm{~F}$. Voigt, "Die Einwirkungen der Verkehrsmittel auf die wirtschaftliche Struktur des Raumes - dargestellt am Beispiel Nordbayerns" in Die Nürnberger Hochschule im fränkischen Raum 1955. Nürnberg: Glock und Lutz, 1955. F. Voigt, Die gestaltende Kraft der Verkehrsmittel in wirtschaftlichen Wachstumsprozessen. Untersuchung der langfristigen Auswirkungen von Eisenbahn und Kraftwagen in einem Wirtschaftsraum ohne besondere Standortvorteile. Bielefeld: Kirschbaum, 1959. H. Weigelt, "Bayerische Nebenbahnen im Strukturwandel đer Flächenbedienung", Die Bundesbahn, 60(1984), pp. 153-162.

31 The impacts of the railway on all aspects of the society are shown by: F. Schnabel 1987, op. cit.; W. Schivelbusch, Geschichte der Bisenbahnreise. Zur Industrialisierung von Raum und Zeit. München, Wien: Hanser, 1977; F. Voigt, Die volkswirtschaftliche Bedeutung des Verkehrssystems. Berlin: Duncker und Humblot, 1960.

32 O. Lang, "Die Eisenbahn in der Weimarer Zeit" in Zug der Zeit - Zeit der Zïge: Deutsche Eisenbahnen 1835-1985, Vol. 2. Berlin: W.J. Siedler Verlag, 1985, pp. 654-660. 